\title{
EDAPHIC ATTRIBUTES OF A CROP-LIVESTOCK INTEGRATION SYSTEM IN THE CERRADO BIOME ${ }^{1}$
}

\author{
SIDINEI JULIO BEUTLER ${ }^{2}$, MARCOS GERVASIO PEREIRA ${ }^{2 *}$, ARCÂNGELO LOSS ${ }^{3}$, ADRIANO PERIN $^{4}$, \\ CRISTIANE FIGUEIRA DA SILVA ${ }^{5}$
}

\begin{abstract}
A significant increase in the use of integrated farming systems have been observed in the Brazilian Cerrado, such as crop-livestock integration (CLI), which combined with the no-tillage system (NTS) have shown significant influence on soil properties. Therefore, the objective of this work was to evaluate the influence of a CLI system on the chemical, physical and microbiological soil characteristics, in an area in the Cerrado biome, Montividiu, State of Goias, Brazil. The soil fertility, remaining phosphorus (Prem), total organic carbon (TOC), total nitrogen (Nt), aggregate stability (geometric mean diameter - GMD), microbial respiration $\left(\mathrm{C}-\mathrm{CO}_{2}\right)$ and easily-extractable glomalin-related soil protein (EE-GRSP) were evaluated. Soil samples were collected at depth of 0-5 and 5-10 cm in three areas with: CLI (13 years of annual rotation with Urochloa ruziziensis); Urochloa decumbens pasture (15 years of implementation); and native Cerrado vegetation. The CLI area had higher $\mathrm{pH}, \mathrm{Mg}, \mathrm{P}$ available $(0-10 \mathrm{~cm})$ and Prem $(5-10 \mathrm{~cm})$ values compared to the other areas, and equal values of TOC, Nt, EE-GRSP $(0-10 \mathrm{~cm})$ and aggregate stability $(5-10 \mathrm{~cm})$ compared to the pasture area. The CLI had no differences in $\mathrm{C}-\mathrm{CO}_{2}$ emissions compared to the Cerrado, but had lower rates compared to the pasture. The $\mathrm{P}$ available and Prem were sensitive indicators to show the differences between the CLI and pasture systems, with higher contents in the CLI area. The TOC and Nt indicators had no differences between these two systems. The GMD results indicated a better aggregation in the pasture $(0-5 \mathrm{~cm})$ compared to the CLI area, while the EE-GRSP were similar in these areas. The total values of $\mathrm{C}-\mathrm{CO}_{2}$ emission from the soil aggregates showed the stability of respirometry rates in the CLI and Cerrado areas.
\end{abstract}

Keywords: Brachiaria. Remaining phosphorus. $\mathrm{C}-\mathrm{CO}_{2}$ accumulation. Aggregation. Glomalin.

\section{ATRIBUTOS EDÁFICOS SOB SISTEMA DE INTEGRAÇÃO-LAVOURA PECUÁRIA NO BIOMA CERRADO}

RESUMO - No Cerrado brasileiro têm-se observado um aumento na adoção de sistemas integrados de cultivo, como a integração lavoura-pecuária (ILP), aliada ao sistema de plantio direto (SPD), os quais vêm exercendo considerável influência nos atributos do solo. O objetivo deste estudo foi avaliar a influência do sistema de integração lavoura-pecuária (ILP) sob alguns atributos químicos, físicos e microbiológicos do solo sob Cerrado, Montividiu, Goiás. Foram avaliados a fertilidade do solo, fósforo remanescente (Prem), carbono orgânico total $(\mathrm{COT})$, nitrogênio total $(\mathrm{Nt})$, estabilidade de agregados (diâmetro médio geométrico - DMG), respiração microbiana $(\mathrm{C}-\mathrm{CO} 2)$ e a proteína do solo relacionada à glomalina - facilmente extraível (PSRG-FE). Coletaram-se amostras de solo nas profundidades de 0-5 e 5-10 cm, em três áreas: ILP (13 anos de rotação anual com Urochloa ruziziensis); pastagem de $U$. decumbens (15 anos de implantação); e Cerrado nativo. A área de ILP apresentou maiores valores de $\mathrm{pH}, \mathrm{Mg}, \mathrm{P}$ disponível $(0-10 \mathrm{~cm})$ e Prem $(5-10 \mathrm{~cm})$ que as demais áreas, e valores similares de COT, Nt, PSRG-FE $(0-10 \mathrm{~cm})$ e estabilidade de agregados $(5-10 \mathrm{~cm})$ à área de pastagem. A ILP não alterou as emissões de $\mathrm{C}-\mathrm{CO}_{2}$ em relação ao Cerrado, mas reduziu essas taxas em relação à pastagem. O Pava e Prem foram indicadores sensíveis para evidenciar diferenças entre os sistemas de ILP e pastagem, com níveis mais elevados no ILP. Enquanto os indicadores COT e NT não mostraram diferenças entre estes dois sistemas. O DMG indicou maior agregação na pastagem $(0-5 \mathrm{~cm})$ em comparação com a ILP, enquanto a PSRG-FE não mostrou diferenças entre essas áreas. A emissão de $\mathrm{C}_{-} \mathrm{CO}_{2}$ indicou estabilidade nas taxas de respirometria no ILP e no Cerrado.

Palavras-chave: Braquiária. Fósforo remanescente. Acúmulo de $\mathrm{C}-\mathrm{CO}_{2}$. Agregação. Glomalina.

\footnotetext{
*Corresponding author

${ }^{1}$ Received for publication in $05 / 25 / 2015$; accepted in $05 / 23 / 2016$.

Paper extracted from the master thesis of the first author.

${ }^{2}$ Department of Soil, Universidade Federal Rural do Rio de Janeiro, Seropédica, RJ, Brazil; s.parana@yahoo.com.br, mgervasiopereira01@gmail.com.

${ }^{3}$ Department of Rural Engineering, Universidade Federal de Santa Catarina, Florianópolis, SC, Brazil; arcangelo.loss@ufsc.br.

${ }^{4}$ Instituto Federal de Educação, Ciência e Tecnologia Goiano, Rio Verde, GO, Brazil; perinrj@yahoo.com.br.

${ }^{5}$ Forestry Institute, Universidade Federal Rural do Rio de Janeiro, Seropédica, RJ, Brazil; cfigueirasilva@yahoo.com.br.
} 


\section{INTRODUCTION}

Cerrado is the second largest biome in Brazil, with an area of approximately 204.7 million hectares, representing about $24 \%$ of the country's total area (IBGE, 2004). It is located in the central region of Brazil, where the State of Goias stands out with approximately $97.0 \%$ of its area in the Cerrado biome (IBGE, 2004). According to Loss et al. (2012), the main use of the Cerrado soils was for pastures (extensive grazing) until the 1970s. Then, these areas were converted to annual crops, with conventional tillage system (CTS) consisted of plowing and harrowing. Subsequently, with the emergence of conservation practices, the CTS was replaced by the no-tillage system (NTS), and more recently, part of the NTS is being combined to crop-livestock integration (CLI).

The Cerrado region had a significant increase in the use of integrated farming systems, such as CLI combined with the NTS, which have shown potential for carbon $(\mathrm{C})$ and nitrogen $(\mathrm{N})$ accumulation in the soil (LOSS et al., 2011). The use of perennial grasses in CLI, such as Urochloa spp., either intercropped, in succession or rotation with annual crops can minimize soil degradation, due to the beneficial effect of these grasses in soil physical attributes, and also increase its stock of C (SALTON et al., 2011; LOSS et al., 2011) and reduce emissions of greenhouse gases into the atmosphere (BALBINO; CORDEIRO; MARTÍNEZ, 2011).

The aggregate stability is a physical attribute that can be affected by the CLI system implementation (SALTON et al., 2008; 2011; LOSS et al., 2011). According to Loss et al. (2011), the use of Urocholoa spp. in NTS with CLI provides efficient soil cover, limiting raindrop impacts, maintaining soil moisture and temperature, enabling a better root development to crops and increases microbial activity, which contributes to create a more favorable environment for soil aggregation.

Regarding the microorganisms, Ramos et al. (2012) emphasizes that the CLI system contributes to the arbuscular mycorrhizal fungi (AMF) development. These microorganisms benefit soil attributes through its hyphae and production of glomalin glycoprotein, which has consolidating effect and is closely correlated with the stability of aggregates and the $\mathrm{C}$ and $\mathrm{N}$ in the soil (WRIGHT; GREEN; CAVIGELLI, 2007; LIANG, 2010). According to Sousa et al. (2012), soil characteristics, climate, land use system, agricultural practices, presence and type of vegetation, among other factors, may influence the amount of glomalin produced by the AMF.

The dynamics of phosphorus $(\mathrm{P})$ fractions, on the other hand, is much more complex and depend on various factors related to soil attributes, such as texture (Tokura et al., 2011), management system (Pereira et al., 2010; Bezerra et al., 2015), chemical and organic fertilization (TIRLONI et al., 2009; GUARDINI et al., 2012; BEUTLER et al., 2015) and environmental (biotic and abiotic) factors (RESENDE et al., 2011). Agricultural systems such as CLI, which aims the maintenance of plant cover with minor soil tilling, can modify the dynamics of $\mathrm{P}$ fractions (BEZERRA et al., 2015; BEUTLER at al., 2015).

A large amount of information on the influence of these systems on attributes related to soil fertility, remaining phosphorus (Prem), microbial respiration and glomalin-related soil protein is required to verify whether the CLI system maintain or improve soil quality compared to native vegetation areas and non-degraded pastures. Therefore, the objective of this work was to evaluate the influence of a CLI system on chemical, physical and microbiological soil attributes compared to a pasture and a native Cerrado area in Montividiu, State of Goias (GO), Brazil.

\section{MATERIAL AND METHODS}

This work was carried out at the Vargem Grande Farm, which belongs to the Agropecuaria Peeters company, in Montividiu GO. Soil samples were collected in three different areas: a crop area (17 $19^{\prime} 35.5^{\prime \prime} \mathrm{S}, 51^{\circ} 29^{\prime} 29.7^{\prime \prime} \mathrm{W}$ and $961 \mathrm{~m}$ altitude) under NTS with CLI for 13 years; a Urochloa decumbens pasture area $\left(17^{\circ} 22^{\prime} 04.5^{\prime \prime} \mathrm{S}, 51^{\circ} 29^{\prime} 52.7^{\prime \prime} \mathrm{W}\right.$ and $946 \mathrm{~m}$ altitude) with 15 years of implementation; and an intact Cerrado area $\left(17^{\circ} 22^{\prime} 12.2^{\prime \prime S}\right.$, $51^{\circ} 29^{\prime} 49.8^{\prime \prime} \mathrm{W}$ and $942 \mathrm{~m}$ altitude) for comparisons. These areas have a clayey Oxisol (Red Latosol with clayey texture - Santos el at., 2013); average annual rainfall of $1700 \mathrm{~mm}$; and average annual temperature of $22.5^{\circ} \mathrm{C}$, with rainy and dry seasons well defined (EMBRAPA, 2011).

The crop area was originally covered by native vegetation (Cerradão) and had been used for crop and livestock productions (1958/59-1983/84), pasture for beef cattle with Urochloa decumbens $(1984 / 85-1993 / 94)$ and grain crops (1994/95-2009/10) using conventional tillage system (CTS) (1994/95-1996/97) and NTS with crop rotation (CLI) (1997/98-2009/10).

This area was conducted with crop rotation in the first 13 years of grain crops (1994/95-2006/07), with soybean grown from October to February and maize from February to June. Cotton crops were introduced in the rotation system from the 2007/08 crop season, grown between November 2007 and August 2008. Soybean was grown followed by winter maize in the 2008/09 crop season. Common beans were grown between September and December 2009, and then cotton, between December 2009 and August 2010. The area had a cotton crop when the soil samples were collected (April 2010).

Maize crops were always conducted 
intercropped with brachiaria (Urochloa ruziziensis Germain et Evrard), simultaneously sown in the inter -row, for increased straw production, which was used as grazing for beef cattle in the dry season (June to September), consisting in a CLI system.

The pasture area was also originally covered by native vegetation (Cerradão), which was replaced by rice and soybean crops under CTS for five years (1990/91-1994/95), period in which this area received the latest mineral fertilizer and lime applications. The area was then conducted exclusively with Urochloa decumbens Stapf. for 15 years (1995-2010). No fertilizers were applied in this area after pasture implementation, and animal stocking rate was approximately $1.4 \mathrm{LU} \mathrm{ha}^{-1}$ (livestock units; $1 \mathrm{LU}=450 \mathrm{~kg}$ live weight), always avoiding animal overcrowding.

A Cerrado (Cerradão) area was taken to compare the pasture and CLI areas, as a parameter for discussion of the results found in the anthropogenic areas. In the CLI area, the last liming was performed in 2007 with $3.0 \mathrm{Mg} \mathrm{ha}^{-1}$ of dolomitic limestone (total neutralizing power ratio of $82 \%$ ) to rise the base saturation to $60 \%$. The average yield of the crops in CLI area were $3,840 \mathrm{~kg} \mathrm{ha}^{-1}$ (soybean), $5,922 \mathrm{~kg} \mathrm{ha}^{-1}$ (winter maize intercropped with brachiaria), 2,520 kg ha-1 (common beans) and 312 $\mathrm{kg} \mathrm{ha}^{-1}$ (cotton). The average dry matter produced in the evaluated period was $5.55 \mathrm{Mg} \mathrm{ha}^{-1}$ in the Cerrado area, $4.25 \mathrm{Mg} \mathrm{ha}^{-1}$ in the CLI area and $2.56 \mathrm{Mg} \mathrm{ha}^{-1}$ in the pasture area.

The CLI area was used as pasture for beef cattle after the maize harvest, which was benefited by the maize residues in the brachiaria. The cattle remained in the area for approximately 70 days, from July to September, at stocking rate of approximately 3.0 LU ha ${ }^{-1}$. The animals were then taken out of the area and, as soon as the first rains occurred, a topdressing fertilization was performed for the brachiaria with $200 \mathrm{~kg} \mathrm{ha}^{-1}$ of a $\mathrm{N}$ and $\mathrm{K}$ formulation $(20: 20)$ in the first half of September. The brachiaria regrew and, when the area was completely covered with grass, a desiccation was performed and a new crop rotation was implemented.

The pasture, CLI and Cerrado areas were under the same topographical (flat) and edaphoclimatic conditions. Soil samples were collected at depth of 0-5 and 5-10 cm, using five composite samples (replications) for each depth. Disaggregated soil samples were collected for fertility analysis, evaluating the total nitrogen $(\mathrm{Nt})$, total organic carbon (TOC), remaining phosphorus (Prem) and easily-extractable glomalin-related soil protein (EE-GRSP). Aggregated soil samples were collected for stability evaluation and $\mathrm{CO}_{2}$ respirometry. The disaggregated soil samples were air dried and sieved in a $2.00 \mathrm{~mm}$ mesh sieve. The aggregated soil samples were sieved in an 8 and then in a $4 \mathrm{~mm}$ mesh sieves for analysis of aggregates.

Soil fertility analysis ( $\mathrm{Ca}, \mathrm{Mg}, \mathrm{Al}, \mathrm{Na}, \mathrm{K}, \mathrm{P}$ available, $\mathrm{H}^{+} \mathrm{Al}$ and $\mathrm{pH}$ in $\mathrm{H}_{2} \mathrm{O}$ ) was performed according to the Embrapa (1997). Prem was evaluated according to Alvarez and Fonseca (1990). TOC and Nt analysis were performed through an elemental analyzer coupled to a mass spectrometer (Carlo Erba, Delta Plus) in the Isotopic Ecology Laboratory (CENA-USP) in Piracicaba (SP).

A wet sieve was used, in order to determine the aggregate classes distribution $(8.0 \geq \varnothing>2.0$, $2.0 \geq \varnothing>1.0, \quad 1.0 \geq \varnothing>0.5, \quad 0.5 \geq \varnothing>0.25 \quad$ and $0.25 \geq \varnothing>0.105 \mathrm{~cm})$ and calculate the aggregates geometric mean diameter (mm) (EMBRAPA, 1997).

The $\mathrm{C}-\mathrm{CO}_{2}$ evaluation was performed following the method proposed by Mendonça and Matos (2005). Fifty grams of aggregates of 8-4 mm with moisture of $60 \%$ of field capacity, $30 \mathrm{ml}$ of water and $30 \mathrm{ml}$ of sodium hydroxide $(\mathrm{NaOH} 0.5$ mol L $\mathrm{L}^{-1}$ ) was placed in a $500 \mathrm{~cm}^{3}$ glass to capture the $\mathrm{CO}_{2}$. The glass containers ( 5 repetitions per land use system) were hermetically sealed and incubated for 52 days, arranged in a randomized design, at room temperature (inside the laboratory) kept at $25^{\circ} \mathrm{C}$ by a cooling system. The determination of the evolved $\mathrm{CO}_{2}$ was performed by titration with $\mathrm{HCl}$ at $0.25 \mathrm{~mol}$ $\mathrm{L}^{-1}$ in the presence of excess of $\mathrm{BaCl}_{2}$.

$\mathrm{CO}_{2}$ evaluations were performed from the $1^{\text {st }}$ to the $8^{\text {th }}$ day every day, from the $8^{\text {th }}$ to the $28^{\text {th }}$ every two days and from the $28^{\text {th }}$ to the $52^{\text {nd }}$ every four days. All evaluations were carried out at the same time. The results were expressed as $\mathrm{mg}$ of $\mathrm{CO}_{2}$ per $100 \mathrm{~g}$ of aggregates. The results were given by the total sum (accumulation) of $\mathrm{CO}_{2}$ after the 52 days of incubation.

Easily-extractable glomalin-related soil protein (EE-GRSP) was obtained through extraction in an autoclave, using $1 \mathrm{~g}$ of soil and $8 \mathrm{ml}$ of sodium

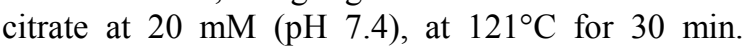
Subsequently, a centrifugation at $5000 \mathrm{x}$ g for $20 \mathrm{~min}$ was performed and the supernatant was removed for protein quantification. Glomalin quantification (Bradford) was performed using bovine albuminserum as standard (Wright et al., 1996). Glomalin concentrations of both fractions were converted to $\mathrm{mg} \mathrm{g}^{-1}$ of soil, considering the total volume of the supernatant and soil dry weight.

A completely randomized design was used, consisting of three areas (pasture, CLI and Cerrado). The results were subjected to the Lilliefors test to assess the normality of errors, and to the Cochran and Barttlet test to verify the homogeneity of variances. Then the data were subjected to the $\mathrm{F}$ test and analysis of variance (ANOVA). The significant data in the $\mathrm{F}$ test at $5 \%$ had their means compared by the Tukey test at 5\%. The Pearson correlation analysis was also performed through the $t$ test at $5 \%$.

\section{RESULTS AND DISCUSSION}


Table 1 shows the results of fertility analysis and Prem. The Cerrado area had the lowest $\mathrm{pH}$ values, which can be explained by the lower $\mathrm{Ca}$ and $\mathrm{Mg}$ contents $(5-10 \mathrm{~cm})$ and the highest $\mathrm{Al}$ contents $(0-10 \mathrm{~cm})$. No Al was found in the CLI and pasture areas. The CLI area was periodically subjected to liming, and the pasture area had liming for about 15 years, when it had soybean crops, which explains their lower Al content.

Table 1. $\mathrm{pH}$ values, nutrients, hydrogen + aluminum and remaining phosphorus in different soil management systems in the Cerrado biome.

\begin{tabular}{|c|c|c|c|c|c|c|c|c|}
\hline \multirow{3}{*}{$\begin{array}{c}\text { Evaluated } \\
\text { systems }\end{array}$} & \multirow{2}{*}{$\mathrm{pH}\left(\mathrm{H}_{2} \mathrm{O}\right)$} & $\mathrm{Ca}$ & $\mathrm{Mg}$ & $\mathrm{K}$ & $\mathrm{Al}$ & $\mathrm{H}+\mathrm{Al}$ & Pava & Prem \\
\hline & & \multicolumn{5}{|c|}{ - $\mathrm{cmol}_{\mathrm{c}} \mathrm{kg}^{-1}$} & \multicolumn{2}{|c|}{---mg kg-1--- } \\
\hline & \multicolumn{8}{|c|}{$0-5 \mathrm{~cm}$} \\
\hline Pasture & $4.97 \mathrm{~b}$ & $2.94 \mathrm{a}$ & $5.20 \mathrm{~b}$ & $0.12^{\mathrm{ns}}$ & $0.00 \mathrm{~b}$ & $8.29 \mathrm{~b}$ & $2 b$ & $24.28 \mathrm{ab}$ \\
\hline CLI & $5.65 \mathrm{a}$ & $2.52 \mathrm{~b}$ & $7.50 \mathrm{a}$ & $0.16^{\mathrm{ns}}$ & $0.00 \mathrm{~b}$ & $6.76 \mathrm{c}$ & $8 \mathrm{a}$ & $25.66 \mathrm{a}$ \\
\hline Cerrado & $4.16 \mathrm{c}$ & $3.08 \mathrm{a}$ & $5.30 \mathrm{~b}$ & $0.13^{\text {ns }}$ & $0.41 \mathrm{a}$ & $15.09 \mathrm{a}$ & $2 \mathrm{~b}$ & $20.89 \mathrm{~b}$ \\
\hline \multirow[t]{2}{*}{ CV (\%) } & 4.79 & 7.08 & 11.86 & 21.80 & 14.02 & 5.69 & 25.02 & 9.74 \\
\hline & \multicolumn{8}{|c|}{$5-10 \mathrm{~cm}$} \\
\hline Pasture & $4.77 \mathrm{~b}$ & $2.50 \mathrm{a}$ & $3.56 \mathrm{~b}$ & $0.07^{\mathrm{ns}}$ & $0.00 \mathrm{~b}$ & $9.11 \mathrm{~b}$ & $4 \mathrm{~b}$ & $21.98 \mathrm{~b}$ \\
\hline CLI & $5.36 \mathrm{a}$ & $2.40 \mathrm{a}$ & $5.58 \mathrm{a}$ & $0.08^{\mathrm{ns}}$ & $0.00 \mathrm{~b}$ & $7.51 \mathrm{~b}$ & $10 \mathrm{a}$ & $25.50 \mathrm{a}$ \\
\hline Cerrado & $3.93 \mathrm{c}$ & $0.68 \mathrm{~b}$ & $1.06 \mathrm{c}$ & $0.08^{\mathrm{ns}}$ & $0.41 \mathrm{a}$ & $11.97 \mathrm{a}$ & $1 \mathrm{c}$ & $19.87 \mathrm{~b}$ \\
\hline CV (\%) & 3.42 & 14.46 & 13.51 & 29.88 & 10.15 & 10.28 & 22.98 & 9.76 \\
\hline
\end{tabular}

Means followed by the same letter in the column did not differ by the Tukey test at $5 \%$; ${ }^{\text {ns }=}$ non-significant by the $\mathrm{F}$ test; $\mathrm{CV}=$ coefficient of variation; $\mathrm{CLI}=$ crop-livestock integration. All areas had sodium (Na) values equals to 0 (zero); $\mathrm{Ca}=$ exchangeable calcium; $\mathrm{Mg}=$ exchangeable magnesium; $\mathrm{K}=$ exchangeable potassium; $\mathrm{H}+\mathrm{Al}=$ exchangeable hydrogen + aluminum; $\mathrm{Al}=$ exchangeable aluminum; Pava = available phosphorus; Prem = remaining phosphorus.

The fertility results found in the CLI area were due to the fertilization management, that has been constant over the years. However, each crop received a specific rate (Soybean: $360 \mathrm{~kg} \mathrm{ha}^{-1}$ of 02:20:18 $+20 \mathrm{~g} \mathrm{ha}^{-1}$ of Mo $+6 \mathrm{~g} \mathrm{ha}^{-1}$ of Co at sowing; Maize + brachiaria: $320 \mathrm{~kg} \mathrm{ha}^{-1}$ of 08:20:20 $+0,6 \%$ of $\mathrm{Zn}$ at sowing and $60 \mathrm{~kg} \mathrm{ha}^{-1}$ of $\mathrm{N}$ approximately 40 days after maize emergence; Common beans: $400 \mathrm{~kg} \mathrm{ha}^{-1}$ of $05: 20: 10$ at sowing and $40 \mathrm{~kg} \mathrm{ha}^{-1}$ of $\mathrm{N}$ approximately 28 days after emergence; Cotton: $550 \mathrm{~kg} \mathrm{ha}^{-1}$ of 10:30:10 at sowing and $200 \mathrm{~kg} \mathrm{ha}^{-1}$ of NK (20:20) approximately 40 days after emergence). The liming (dolomitic limestone) explains the higher amounts of $\mathrm{Mg}$ and thus, the $\mathrm{pH}$ in the CLI area.

The $\mathrm{Ca}$ content in the pasture area were higher $(0-5 \mathrm{~cm})$ or equal $(5-10 \mathrm{~cm})$ to the CLI area. This result was due to the lime addition and calcium recycling via plant residue decomposition. The pasture area had higher $\mathrm{Mg}$ contents compared to the Cerrado area at $5-10 \mathrm{~cm}$. This result may be related to the accentuated and constant cycling and renewal process of the pasture root system at greater depths.

The $\mathrm{K}$ contents of the areas was not different, which can be explained by the straw cycling and subsequent release of this nutrient. The potassium fertilization affected the CLI area, which can be correlated to the highest dry biomass production found in the Cerrado (5.55 $\mathrm{Mg} \mathrm{ha}^{-1}$ ) compared to the CLI area $\left(4.25 \mathrm{Mg} \mathrm{ha}^{-1}\right)$. The pasture area had $\mathrm{K}$ content similar to the other areas probably due to the absorption and accumulation of $\mathrm{K}$ by the brachiaria (CRUSCIOL; BORGHI, 2007) and later release into the soil through straw decomposition, which produced only $2.56 \mathrm{Mg} \mathrm{ha}^{-1}$ of dry matter. Similar results were reported by Loss et al. (2012) and
Guareschi, Perin and Pereira (2012), who found K contents $(0-5 \mathrm{~cm})$ of about $0.20 \mathrm{cmol}_{\mathrm{c}} \mathrm{kg}^{-1}$ for CLI and Cerrado areas in Goias.

The CLI area had the highest $\mathrm{P}$ content, which are related to the phosphate fertilizer applications and maintenance of crop residues on the soil surface. The pasture area had grater $\mathrm{P}$ contents $(5-10 \mathrm{~cm})$ compared to the Cerrado area. The pasture (brachiaria) root system favored the $\mathrm{P}$ cycling in the soil, providing more $\mathrm{P}$-available to plants, showing the importance of using grasses with root system that emit large number of thin and deep roots. This characteristic is one of the reasons that justify the implementation of grasses in crop rotation systems for grain production, such as crop-livestock integration.

The CLI area had the greatest Prem content due to the use of a cultivation system with different plant species in the crop rotation, which enable an intense cycling of residues in the soil surface, according Pereira et al. (2010) and Bezerra et al. (2015). However, the Prem content in the CLI area was not different from pasture area at depth of $0-5$ $\mathrm{cm}$.

The cycling of residues releases organic acids of low molecular weight, which can block phosphate adsorption sites (TIRLONI et al., 2009), thus increasing the Prem contents in the soil. Phosphorus fertilization was performed in the CLI area and also for 15 years in the pasture area when it had soybean crops. These fertilizations probably caused filling of some charge sites of iron oxides, contributing to reduce phosphorus adsorption.

The TOC and Nt content of the pasture and CLI areas had similar results (Table 2), and the Cerrado area differed from them with higher rates. 
These results confirm those found by Fonseca et al. (2007), in the Cerrado of Goias, comparing topsoil layer characteristics in no-tillage system with brachiaria and native vegetation (Cerrado) areas.

Table 2. Total Organic Carbon (TOC), total nitrogen $(\mathrm{Nt})$ and carbon/nitrogen ratio $(\mathrm{C} / \mathrm{N})$ in different soil management systems in the Cerrado.

\begin{tabular}{|c|c|c|c|}
\hline \multirow{3}{*}{ Evaluated Systems } & TOC & $\mathrm{Nt}$ & \multirow{2}{*}{$\mathrm{C} / \mathrm{N}$} \\
\hline & \multicolumn{2}{|c|}{ 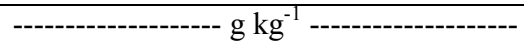 } & \\
\hline & \multicolumn{3}{|c|}{$0-5 \mathrm{~cm}$} \\
\hline Pasture & $36.43 \mathrm{~b}$ & $1.94 \mathrm{~b}$ & $18.84 \mathrm{a}$ \\
\hline CLI & $29.61 \mathrm{~b}$ & $1.69 \mathrm{~b}$ & $17.55 \mathrm{~b}$ \\
\hline Cerrado & $65.40 \mathrm{a}$ & $3.45 \mathrm{a}$ & $18.99 \mathrm{a}$ \\
\hline \multirow[t]{2}{*}{ CV $(\%)$} & 13.61 & 14.70 & 2.26 \\
\hline & \multicolumn{3}{|c|}{$5-10 \mathrm{~cm}$} \\
\hline Pasture & $24.20 \mathrm{~b}$ & $1.24 \mathrm{~b}$ & $19.47 \mathrm{a}$ \\
\hline CLI & $24.27 \mathrm{~b}$ & $1.32 \mathrm{~b}$ & $18.33 \mathrm{~b}$ \\
\hline Cerrado & $33.61 \mathrm{a}$ & $1.93 \mathrm{a}$ & $17.39 \mathrm{~b}$ \\
\hline $\mathrm{CV}(\%)$ & 8.33 & 8.03 & 3.60 \\
\hline
\end{tabular}

Means followed by the same letter in the column did not differ by the Tukey test at $5 \%$; CV $=$ Coefficient of variation; $\mathrm{CLI}=$ Crop-livestock integration .

The similarity of the TOC and Nt results in the CLI and pasture areas denotes their stability in CLI system. According to Salton et al. (2008), well-managed pasture areas are considered systems with great stability in carbon and nitrogen dynamics. Considering that the pasture area evaluated was implemented 15 years ago and conducted in a system with appropriate productive capacity of the area, avoiding excessive grazing, the content of TOC and $\mathrm{Nt}$ were not good indicators for differentiate the CLI and pastures areas.

The greatest TOC and $\mathrm{Nt}$ content in the Cerrado area may be due to the microclimate stability under the forest canopy, where the organic material deposition, mainly leaves, is constantly providing better conditions for establishment and maintenance of microbial populations in the soil. The Cerrado area produced $5.55 \mathrm{Mg} \mathrm{ha}^{-1}$ of dry matter, while the CLI area produced $4.25 \mathrm{Mg} \mathrm{ha}^{-1}$ and the pasture area $2.56 \mathrm{Mg} \mathrm{ha}^{-1}$. Soils with high organic matter content from phytomass tend to maintain a better stability of microbial population throughout the year, which can be attributed to the wealth of ecological niches and the heterogeneity of carbon sources (GRAYSTON et al. 2001).

The CLI area had lower $\mathrm{C} / \mathrm{N}$ ratio $(0-5$ and $5-10 \mathrm{~cm})$ compared to the pasture and equal to the Cerrado area at $5-10 \mathrm{~cm}$. The highest $\mathrm{C} / \mathrm{N}$ ratio in the pasture area is due to the origin of plant residues, which was exclusively from $\mathrm{C}_{4}$ plants (brachiaria), which have high $\mathrm{C} / \mathrm{N}$ ratio (CRUSCIOL and
BORGHI, 2007). The lower values of $\mathrm{C} / \mathrm{N}$ ratio in the CLI area may be related to different organic residues sources in this area, in which plants of different $\left(\mathrm{C}_{3}\right.$ and $\left.\mathrm{C}_{4}\right)$ photosynthetic cycle (soybean, common bean, maize, cotton and brachiaria) are used, differing from pasture areas, which had only $\mathrm{C}_{4}$ plants and from the Cerrado with mostly $\mathrm{C}_{3}$ plants.

The stability of aggregates was evaluated by their geometric mean diameter (GMD) (Table 3) and mass distribution in the different aggregates classes (Figure 1).

The CLI area presented the lowest GMD values for both depths, however, these values were not statistically different from the pasture area at $5-10 \mathrm{~cm}$. The pasture area had a better stability of aggregates compared to the CLI area under NTS due to its abundant root system (SALTON et al., 2008). The anthropogenic influence in the CLI areas, through sowing and mechanized fertilization, caused little perturbations in soil aggregation. Costa Junior et al. (2011) evaluated the aggregation in Cerrado soils and found that the adoption of management systems, except pasture, disrupt aggregates, especially on systems with greater intensity of soil disturbance. However, this result was found only at depth of $0-5 \mathrm{~cm}$, since similar values were found at 5 $-10 \mathrm{~cm}$ in the pasture areas, indicating that the CLI system has structural stability equal to the pasture after 13 years of implementation and similar TOC and $\mathrm{Nt}$ contents, with emphasis to the depth of 5-10 $\mathrm{cm}$. 
Table 3. Geometric mean diameter (GMD) of aggregates, total values of $\mathrm{C}-\mathrm{CO}_{2}$ emitted after 52 days of incubation of aggregate and easily-extractable glomalin-related soil protein (EE-GRSP) in different soil management systems in the Cerrado biome.

\begin{tabular}{|c|c|c|c|c|}
\hline \multirow{3}{*}{ Depth $(\mathrm{cm})$} & \multicolumn{3}{|c|}{ Evaluated Systems } & \multirow{3}{*}{$\mathrm{CV}(\%)$} \\
\hline & Pasture & CLI & Cerrado & \\
\hline & \multicolumn{3}{|c|}{--------------- GMD (mm) --------------- } & \\
\hline $0-5$ & $3.726 \mathrm{a}$ & $2.973 \mathrm{~b}$ & $3.925 \mathrm{a}$ & 11.23 \\
\hline \multirow[t]{2}{*}{$5-10$} & $3.323 \mathrm{ab}$ & $2.900 \mathrm{~b}$ & $4.014 \mathrm{a}$ & 18.66 \\
\hline & \multicolumn{4}{|c|}{ 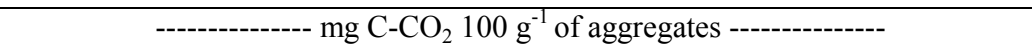 } \\
\hline $0-5$ & $62.4 \mathrm{a}$ & $48.8 \mathrm{~b}$ & $43.7 \mathrm{~b}$ & 12.46 \\
\hline $5-10$ & $28.8 \mathrm{a}$ & $22.0 \mathrm{~b}$ & $18.1 \mathrm{~b}$ & 15.40 \\
\hline \multicolumn{5}{|c|}{ EE-GRSP ( $\mathrm{mg} \mathrm{g}^{-1}$ of soil) } \\
\hline $0-5$ & $1.58 \mathrm{~b}$ & $1.53 \mathrm{~b}$ & $3.39 \mathrm{a}$ & 21.13 \\
\hline $5-10$ & $1.56 \mathrm{~b}$ & $1.05 \mathrm{~b}$ & $2.97 \mathrm{a}$ & 29.03 \\
\hline
\end{tabular}

Means followed by the same letter in the line did not differ by the Tukey test at $5 \%$; $\mathrm{CV}=$ Coefficient of variation; CLI $=$ Crop-livestock integration.

The difference or similarity in GMD depend on the aggregate mass distribution in the different sieves, with emphasis on the class of larger diameter (Figure 1), in which the exactly same pattern of GMD was found. These results showed factors that favor aggregation in all these areas, i.e., the formation and stabilization of aggregates of large diameter (8.00 $2.00 \mathrm{~mm})$.
The brachiaria roots probably had mechanical action to unite soil particles (SIX et al., 2004) and chemical and organic substances with consolidating action released in the CLI and pasture areas (SALTON et al., 2008; KASPER et al., 2009). The action of fungal hyphae may also be critical to soil aggregation (DENEF; SIX, 2005), mainly in the Cerrado area, which had no influence of anthropogenic activities.

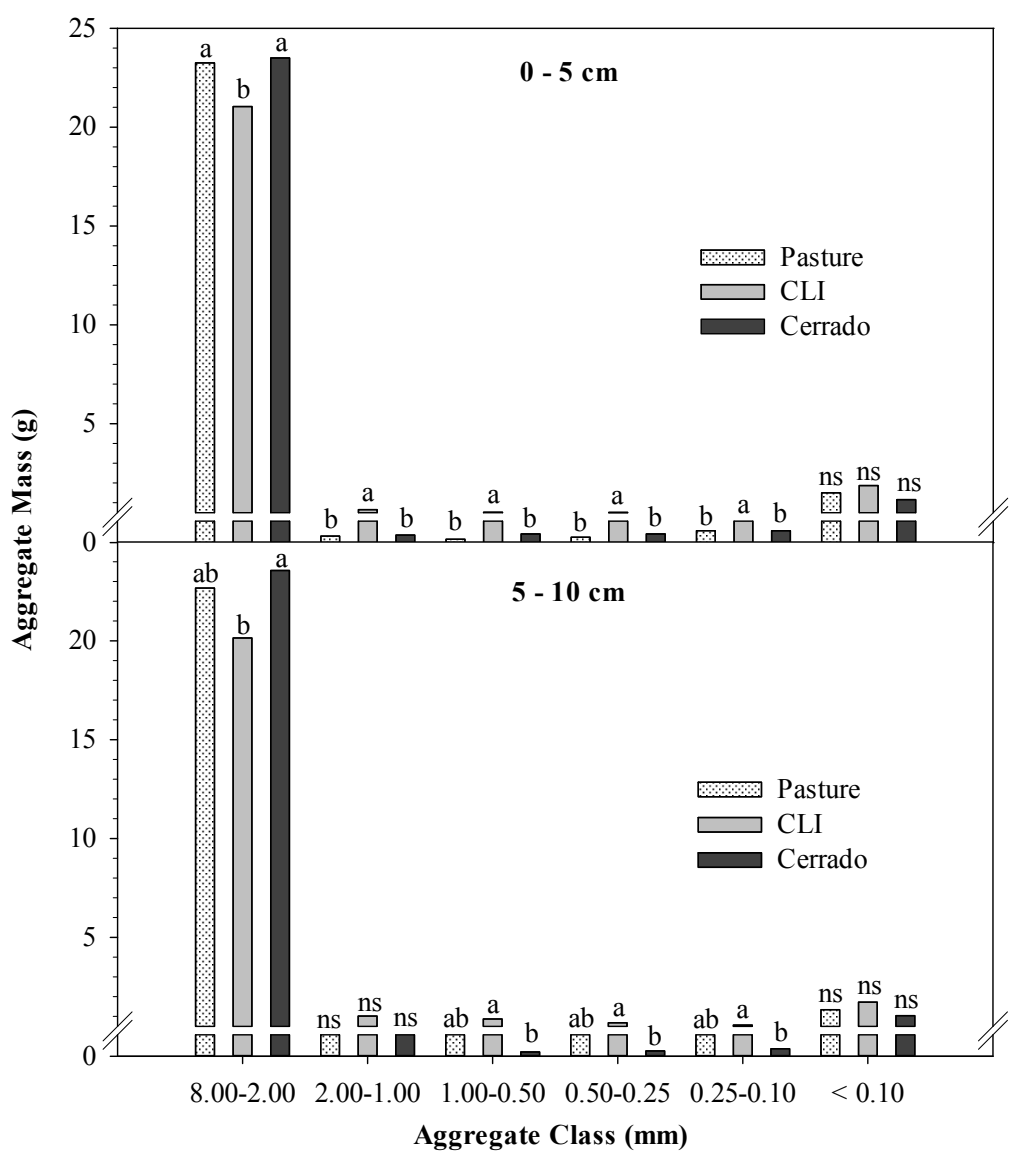

Figure 1. Aggregate mass distribution in different sieves after wet sieving process. Aggregate class with the same letter do not differed between the areas evaluated by the Tukey test at 5\%. ns = not significant by the $\mathrm{F}$ test at $5 \%$. 
The aggregate classes smaller than 8.00-2.00 $\mathrm{mm}$, which were found mostly in the CLI areas, had the highest aggregate mass in both layers evaluated. These results showed a positive influence of plant diversity in the CLI area, and especially by the brachiaria roots, which favor the formation of aggregates in classes smaller than 8.00-2.00 mm. The greater mass of aggregates $>0.25 \mathrm{~mm}$ in CLI area, mainly at $0-5 \mathrm{~cm}$, indicates greater protection of TOC and $\mathrm{Nt}$ against microbial decomposition (SIX; ELLIOTT; PAUSTIAN, 2000), confirming the results found by Loss et al. (2011) in Cerrado and NTS areas, with and without CLI.

The $\mathrm{C}-\mathrm{CO}_{2}$ emitted by aggregates, accumulated over 52 days of incubation, had higher values in the pasture area for both layers evaluated (Table 3). The pasture area possibly had microorganisms adapted to feed from organic materials of high $\mathrm{C} / \mathrm{N}$ ratio, thus emitting more $\mathrm{CO}_{2}$ from aggregates. Moreover, non-degraded plant residues of brachiaria pastures may have larger total amounts of $\mathrm{N}, \mathrm{P}, \mathrm{K}, \mathrm{Ca}$ and $\mathrm{Mg}$, and more microorganism activity compared to Cerrado and crop areas (KLUTHCOUSKI et al., 2006), due to the development capacity and nutrients accumulation in the biomass of the poaceae (brachiaria) (CRUSCIOL; BORGHI, 2007).

Carneiro et al. (2008) evaluated a Quartzipsamment and an Oxisol (Neossolo Quartzarênico and Latosolo Vermelho - Santos et al., 2013) in the Cerrado biome, comparing areas with continuous pasture (Urochloa decumbens), crops under CTS, NTS and CLI (maize $+U$. decumbens), and found higher respirometry rates in areas with Urochloa sp.

The $\mathrm{C}-\mathrm{CO}_{2}$ emissions in the CLI and Cerrado areas were similar, which is attributed to the similar values of $\mathrm{C} / \mathrm{N}$ ratios (Table 2) that require similar forms of microbial metabolisms. These areas had also similar litterfall amounts $\left(5.55 \mathrm{Mg} \mathrm{ha}^{-1}\right.$ in the Cerrado and 4.25 Mg ha ${ }^{-1}$ in the CLI area).

According to Alexander (1999), carbon is usually the nutrient that limits microbial growth in natural environments, since the amount of inorganic nutrients usually present exceeds the requirements of microbial communities. Therefore, nutritional resources that are readily available for microorganisms (mainly carbon) are reduced over time, showing a stability tendency in respirometry rates, such as those found in the CLI and Cerrado areas.

The layer $5-10 \mathrm{~cm}$ had respirometry rates over $50 \%$ lower than the layer $0-5 \mathrm{~cm}$, which is attributed to the also lower TOC and $\mathrm{Nt}$ contents in the layer $5-10 \mathrm{~cm}$ (Table 2). Thus, the greater nutritional sources in the surface layer provide food for soil microorganisms, increasing the consume and breathe.

The Cerrado had higher EE-GRSP values in both depths, probably due to the greater diversity of
AMF, which are related to this protein deposition in the soil (WRIGHT et al., 1996). Angelini et al. (2012) evaluated the AMF diversity in Cerrado areas compared to NTS areas with brachiaria, millet and crotalaria in the Cerrado of Minas Gerais and found higher AMF diversity in the Cerrado area, with some species found only in the Cerrado compared to the other areas. The pasture and CLI areas had similar EE-GRSP values in both depths (Table 3), following the same pattern of the TOC and Nt (Table 2).

The EE-GRSP had positive correlation with the stability of aggregates, represented by the GMD at depths of $0-5(\mathrm{r}=0.61, \mathrm{p}=0.09)$ and $5-10 \mathrm{~cm}$ $(\mathrm{r}=0.99, \mathrm{p}=0.05)$. This protein has also correlation with TOC at depths of $0-5(\mathrm{r}=0.99, \mathrm{p}=0.006)$ and $5-10 \mathrm{~cm}(\mathrm{r}=0.96, \mathrm{p}=0.06)$. Similar results were found by Liang (2010) in areas with different soil management systems. This author emphasizes that the EE-GRSP may be a potential indicator to differentiate tillage systems regarding carbon sequestration in soil horizons.

The positive correlation between glomalin and soil aggregation (GMD) indicates that the glomalin contributes similarly to roots and shoots by the process of aggregation of soil particles, and this effect is more effective than the mycelial process (RILLIG et al., 2002). According to Rillig (2004), the glomalin induces bonds with clay particles, increasing the stability of micro-aggregates, contributing to the physical recovery of the soil.

\section{CONCLUSIONS}

The chemical attributes P-available and P-remaining were sensitive indicators to differentiate the CLI and pastures systems, with greater contents in the CLI area. The TOC and Nt indicators showed no differences between these two systems.

The physical attribute GMD indicated a higher aggregation in the pasture $(0-5 \mathrm{~cm})$ compared to the CLI area, while the microbiological EE-GRSP were no different in these areas.

The total values of $\mathrm{C}-\mathrm{CO}_{2}$ emission from the soil aggregates showed the stability of respirometry rates in the CLI and Cerrado areas.

\section{REFERENCES}

ALEXANDER, M. Biodegradation and bioremediation. 2.ed. New York: Academic, 1999. $453 \mathrm{p}$.

ALVAREZ, V.H.; FONSECA, D.M. Definição de doses de fósforo para determinação da capacidade máxima de adsorção de fosfatos e para ensaios em casa de vegetação. Revista Brasileira de Ciência do Solo, Viçosa, v. 14, n. 14, p. 49-55, 1990. 
ANGELINI, G.A.R. et al. Colonização micorrízica, densidade de esporos e diversidade de fungos micorrízicos arbusculares em solo de Cerrado sob plantio direto e convencional. Semina. Ciências Agrárias, Londrina, v. 33, n. 1, p. 117-132, 2012.

BALBINO, L. C.; CORDEIRO, L.A.M.; MARTÍNEZ, G.B. Contribuições dos Sistemas de Integração Lavoura-Pecuária-Floresta (ILPF) para uma Agricultura de Baixa Emissão de Carbono. Revista Brasileira de Geografia Física, Recife, v. 4, n. 6, p. 1014-1026, 2011.

BEZERRA, R. P.M. et al. A. Frações de fósforo e correlação com atributos edáficos sob sistemas de plantio direto e integração lavoura-pecuária no Cerrado Goiano. Semina. Ciências Agrárias, Londrina, v. 36, n. 6. p. 1287-1306, 2015.

Beutler, S. J.et al. Humic substances and phosphorus fractions in areas with crop-livestock integration, pasture and natural Cerrado Vegetation in Goiás. Tropical and Subtropical Agroecosystems, Yucatan, v. 18, n. 1, p. 11-25, 2015.

CARNEIRO, M.A.C. et al. Atributos bioquímicos em dois solos de cerrado sob diferentes sistemas de manejo e uso. Pesquisa Agropecuária Tropical, Goiânia, v. 38, n. 4, p. 276-283, 2008.

COSTA JUNIOR, C. et al. Nitrogênio e abundância natural de ${ }^{15} \mathrm{~N}$ em agregados do solo no bioma Cerrado. Ensaios e Ciência, Anhanguera, v. 15, n. 2, p. 47-66, 2011.

CRUSCIOL, C. A. C.; BORGHI, E. Consórcio de milho com braquiária: produção de forragem e palhada para o plantio direto. Revista Plantio Direto, Passo Fundo, v. 100, n. 4, p. 10-14, 2007.

DENEF, K.; SIX, J. Clay mineralogy determines the importance of biological versus abiotic processes for macroaggregate formation and stabilization. European Journal of Soil Science, Malden, v. 56, n. 4, p. 469-479, 2005.

EMBRAPA. Centro Nacional de Pesquisa de Solos. Manual de métodos de análise de solo. 2 . ed. Rio de Janeiro, RJ: EMBRAPA, 1997. 212 p.

EMBRAPA. Embrapa Monitoramento por Satélite. Banco de Dados Climáticos do Brasil. Disponível em: $\quad<$ http://www.bdclima.cnpm.embrapa.br/ resultados/balanco.php? $\mathrm{UF}=\& \mathrm{COD}=66>$. Acesso em: 20 Set. 2011.

FONSECA, G.C. et al. Atributos físicos, químicos e biológicos de Latossolo Vermelho Distrófico de Cerrado sob duas rotações de cultura. Pesquisa Agropecuária Tropical, Goiânia, v. 37, n. 1, p. 22-30, 2007.

GRAYSTON, S. J. et al. Accounting of variability in soil microbial communities of temperate upland grassland ecosystem. Soil Biology and Biochemistry, Queensland, v. 33, n. 4-5, p. 533-551, 2001.

GUARESCHI, R. F.; PERIN, A.; PEREIRA, M.G. Deposição de resíduos vegetais, matéria orgânica leve, estoques de carbono e nitrogênio e fósforo remanescente sob diferentes sistemas de manejo no cerrado goiano. Revista Brasileira de Ciência do Solo, Viçosa, v. 36, n. 3, p. 909-920, 2012.

GUARDINI, R. et al. Accumulation of phosphorus fractions in typic Hapludalf soil after long-term application of pig slurry and deep pig litter in a no-tillage system. Nutrient Cycling in Agroecosystems, Dordrecht, v. 93, n. 2, p. 215-225, 2012.

IBGE. Instituto Brasileiro de Geografia e Estatística. Mapa de Biomas do Brasil. Disponível em: $<$ http:// mapas.ibge.gov.br/biomas2/viewer.htm>. Acesso em: 13 fev. 2007.

KASPER, M. et al. Influence of soil tillage systems on aggregate stability and the distribution of $\mathrm{C}$ and $\mathrm{N}$ in different aggregate fractions. Soil and Tillage Research, Helsinki, v. 105, n. 2, p. 192-199, 2009.

LIANG, W.J. Effect of tillage systems on glomalin-related soil protein in a Aquatic Brown Soil. Research Journal of Biotechnology, Indore, v. 5, n. 3, p. 10-13, 2010.

LOSS, A. et al. Agregação, carbono e nitrogênio em agregados do solo sob plantio direto com integração lavoura-pecuária. Pesquisa Agropecuária Brasileira, Brasília, v. 46, n. 10, p. 1269-1276, 2011.

LOSS, A. et al. Densidade e fertilidade do solo sob sistemas plantio direto e integração lavoura-pecuária no Cerrado. Revista de Ciências Agrárias, Belém, v. 55, n. 4, p. 260-268, 2012.

MENDONÇA, E.S.; MATOS, E.S. Matéria orgânica do solo: métodos de análises. Viçosa, MG: UFV, 2005. 107 p.

PEREIRA, M. G. et al. Carbono, matéria orgânica leve e fósforo remanescente em diferentes sistemas de manejo do solo. Pesquisa Agropecuária Brasileira, Brasília, v. 45, n. 5, p.508-514, 2010.

RAMOS, M.L.G. et al. Diversidade de fungos micorrízicos e colonização radicular, em forrageiras solteiras e em consórcio com milho. Bioscience Journal, Uberlândia, v. 8, n. 2, p. 235-244, 2012. 
RESENDE, J.C.F. et al. Phosphorus cycling in a small watershed in the Brazilian Cerrado: impacts of frequent burning. Biogeochemistry,Indore, v. 105, n. 1 , p. 105-118, 2011..

RILLIG, M. C. Arbuscular mycorrhizae, glomalin, and soil aggregation. Canadian Journal of Soil Science, Ottawa,v. 84, n. 4, p. 355-363, 2004.

RILLIG, M. C.; WRIGHT, S. F.; EVINER, V. T. The role of arbuscular mycorrhizal fungi and glomalin in soil aggregation: comparing effects of five plant species. Plant and Soil, Netherlands, v. 238, n. 2, p. 325-333, 2002.

SALTON, J.C. et al. Teor e dinâmica do carbono no solo em sistemas de integração lavoura-pecuária. Pesquisa Agropecuária Brasileira, Brasília, v. 46, n. 10, p. 1349-1356, 2011.

SALTON, J.C. et al. Agregação e estabilidade de agregados do solo em sistemas agropecuários em MS. Revista Brasileira de Ciência do Solo, Viçosa, v. 32, n. 1, p. 11-21, 2008.

SANTOS, H. G. et al. Sistema brasileiro de classificação de solos. 3. ed. Brasília, DF: EMBRAPA, 2013. 353p.

SIX, J. et al. A history of research on the link between agregates, soil biota, and soil organic matter dynamics. Soil and Tillage Research, Helsinki, v. 79, n. 1, p. 7-31, 2004.

SIX, J.; ELLIOTT, E.T.; PAUSTIAN, K. Soil macroaggregate turnover and microaggregate formation: a mechanism for $\mathrm{C}$ sequestration under no-tillage agriculture. Soil Biology and Biochemistry, Queensland, v. 32, n. 14, p. 2099-2103, 2000.

SOUSA, C.S. et al. Glomalina: características, produção, limitações e contribuição nos solos. Semina: Ciências Agrárias, Londrina, v. 33, n. 6, p. 3033-3044, 2012.

TIRLONI, C. et al. Disponibilidade de fósforo em função das adições de calagem e de um bioativador do solo. Ciência e Agrotecnologia, Lavras, v. 33, n. 4, p. 977-984, 2009.

TOKURA, A. M. et al. Dinâmica das formas de fósforo em solos de textura e mineralogia contrastantes cultivados com arroz. Acta Scientiarum. Agronomy, Maringa, v. 33, n. 2, p. 171-179, 2011.

WRIGHT, S.F.; UPADHYAYA, A. A survey of soils for aggregate stability and glomalin, a glycoprotein produced by hyphae of arbuscular mycorrhizal fungi. Plant and Soil, Netherlands, v. 198, n. 1, p. 97-107, 1998.

WRIGHT, S.F.; GREEN, V.S.; CAVIGELLI, M.A. Glomalin in aggregate size classes from three different farming systems. Soil and Tillage Research, Helsinki, v. 94, n. 2, p. 546-549, 2007.

WRIGHT, S.F. et al. Time-course study and partial characterization of a protein on hyphae of arbuscular mycorrhizal fungi during active colonization of roots. Plant and Soil, Netherlands, v. 181, n. 2, p. 193-203, 1996. 